Article

\title{
Bioeconomy Transitions through the Lens of Coupled Social-Ecological Systems: A Framework for Place-Based Responsibility in the Global Resource System
}

\author{
Liesbeth de Schutter ${ }^{1, *}$, Stefan Giljum ${ }^{1}$, Tiina Häyhä ${ }^{2,3}$, Martin Bruckner ${ }^{1} \oplus$, Asjad Naqvi ${ }^{1,3} \oplus$, \\ Ines Omann ${ }^{1}$ (i) and Sigrid Stagl ${ }^{1}$ \\ 1 Institute for Ecological Economics, Vienna University of Economics and Business, 1020 Vienna, Austria; \\ stefan.giljum@wu.ac.at (S.G.); martin.bruckner@wu.ac.at (M.B.); ines.omann@gmx.net (I.O.); \\ sigrid.stagl@wu.ac.at (S.S.) \\ 2 Stockholm Resilience Centre, Stockholm University, 10691 Stockholm, Sweden; tiina.hayha@su.se \\ 3 International Institute for Applied Systems Analysis, 2361 Laxenburg, Austria; naqvi@iiasa.ac.at \\ * Correspondence: liesbeth.de.schutter@wu.ac.at
}

Received: 29 May 2019; Accepted: 9 October 2019; Published: 15 October 2019

\begin{abstract}
Bioeconomy strategies in high income societies focus at replacing finite, fossil resources by renewable, biological resources to reconcile macro-economic concerns with climate constraints. However, the current bioeconomy is associated with critical levels of environmental degradation. As a potential increase in biological resource use may further threaten the capacity of ecosystems to fulfil human needs, it remains unclear whether bioeconomy transitions in high income countries are sustainable. In order to fill a gap in bioeconomy sustainability assessments, we apply an ontological lens of coupled social-ecological systems to explore critical mechanisms in relation to bioeconomy activities in the global resource system. This contributes to a social-ecological systems (SES)-based understanding of sustainability from a high income country perspective: the capacity of humans to satisfy their needs with strategies that reduce current levels of pressures and impacts on ecosystems. Building on this notion of agency, we develop a framework prototype that captures the systemic relation between individual human needs and collective social outcomes on the one hand (micro-level) and social-ecological impacts in the global resource system on the other hand (macro-level). The BIO-SES framework emphasizes the role of responsible consumption (for physical health), responsible production (to reduce stressors on the environment), and the role of autonomy and self-organisation (to protect the reproduction capacity of social-ecological systems). In particular, the BIO-SES framework can support (1) individual and collective agency in high income country contexts to reduce global resource use and related ecosystem impacts with a bioeconomy strategy, (2) aligning social outcomes, monitoring efforts and governance structures with place-based efforts to achieve the SDGs, as well as (3), advancing the evidence base and social-ecological theory on responsible bioeconomy transitions in the limited biosphere.
\end{abstract}

Keywords: bioeconomy; ecosystem functions; human needs; inequality; place-based responsibility; SDGs; social-ecological system; sustainability

\section{Highlights}

- We explore bioeconomy transitions from a social-ecological systems (SES) perspective

- An SES lens allows assessing economic activity in its social and ecological context 
- A sustainable SES perspective reconciles satiable human needs with ecosystem functioning

- We develop an SES-based framework to support place-based bioeconomy transitions

- Embedding the SDGs in the BIO-SES framework creates synergies in monitoring, evaluation, and governance efforts.

\section{Introduction}

Current activities in the bioeconomy are recognized for their multiple and strong links with the UN Sustainable Development Goals (SDGs) [1-3]. Poverty reduction, food security, health, renewable energy, innovation, employment, and climate resilience, among others, are vital contributions of a bioeconomy to wellbeing in society $[1,3,4]$. Furthermore, in the context of climate change, bioeconomy strategies have emerged as social-technical transition processes away from the linear use of fossil carbon to a renewable use of biogenic carbon. Bio-based alternatives are being explored in energy, chemical, health care, and food sectors [5,6] by means of biorefinery-based value chains and biotechnologies $[7,8]$, among others. As a result, the number of national and sub-national bioeconomy strategies is rapidly increasing, both in low, middle and high-income countries [9,10], as well as at national and sub-national levels [11].

Food and non-food bioeconomy activities are an integral part of the global economic system and subject to competition and marginalization in the petrochemical production environment [12]. Market-based bioeconomy transitions are affected by supra-regional policies, (trade) regulations, and commodity price volatility [13], and likely to increase and intensify the extraction of ecosystem functions in the global resource system. Indeed, evidence of environmental degradation supports the implicit assumption that resource users prioritize productive functions of ecosystems over non-productive life supporting functions such as, in particular, biodiversity and climate stabilization [14-17]. Food and agriculture have repeatedly been identified as the main drivers of global environmental change, including deforestation, biodiversity loss, water scarcities, soil degradation, and greenhouse gas emissions $[18,19]$. High income countries, in particular, have been associated with environmental impacts of animal-based diets and high levels of food waste [20-22]. Furthermore, increasing demand for non-food bioeconomy products and services, in particular bioenergy, supports global trade of biobased resources from tropical and sub-tropical regions, thereby inducing ambiguous social and environmental impacts $[23,24]$. Thus, in the context of global challenges in relation to food security and environmental change, questions emerge how bioeconomy transitions in high-income countries can (1) support sustainable development from a global resource use perspective and (2) be comprehensively monitored, evaluated and governed to that end.

There is a general concern about the lack of comprehensive sustainability assessments of evolving bioeconomy activities [3,4,25]. Bioeconomy transitions tend to be assessed according to the 'three pillar' model of sustainability, including a social, economic and environmental dimension of development [26]. However, the multiple levels, sectors, and agents increase complexity to such extent that a comprehensive interpretation of outcomes is hampered or starkly reduced in a model that aims at balancing and integrating social, economic and ecological aspects of economic activity under a common denominator $[27,28]$. In this context, an increasing number of scholars point at shortcomings and risks of the three-pillar approach as the dominant paradigm for sustainable development [29]. Hence, we propose to explore bioeconomy transitions from a coupled social-ecological systems (SES) perspective [30], and to develop a framework that supports a comprehensive and dynamic understanding of coupled social outcomes and ecological impacts of economic activity in the global resource system. The SES perspective provides for an ontological lens that takes the dynamic co-evolution of social and ecological systems at its core: humans are intrinsically dependent on ecosystem functions, as well as a major shaping force in shaping local and global ecosystems [31-33].

In trying to answer the above listed research questions from a holistic perspective, we replace the "three pillar" sustainability framework by an SES perspective (Section 2). We explore different SES literature strands [30,33-37] on insights of critical human-nature dependencies in relation food 
and non-food bioeconomy activities in the global resource system (Section 3). These insights provide the structure of an SES-based framework to formulate, monitor and evaluate bioeconomy transition processes from a place-based perspective (Section 4). To address the responsibility of high-income countries for sustainable, place-based bioeconomy transitions in the global resource system, we show how embedding the SDGs in the BIO-SES framework can give normative direction to desirable outcomes and create synergies in global and local governance efforts (Section 5). In Section 6, we conclude and recommend further research into the potential value of place-based bioeconomy transitions for responsible consumption, production, and social-ecological reproduction as constituents of environmentally safe and socially just societies.

\section{From "Three-Pillar" Sustainability to a Coupled Social-Ecological Systems Perspective}

In high-income countries, bioeconomy strategies are politically supported and implemented as part of industrial strategies that aim at reconciling macro-economic concerns with climate constraints [38-42]. In the EU context, a bioeconomy is defined as "all systems and sectors that rely on biological resources (animals, plants, micro-organisms and derived biomass, including organic waste), their functions and principles, including ecosystems and primary sectors that use and produce biological resources (agriculture, forestry, fisheries and aquaculture) and all economic and industrial sectors that use biological resources for food, feed, bio-based products, energy and services"(p. 27, [43]). Implicitly, a bioeconomy is hereby assumed to be more sustainable than a fossil based economy.

The majority of the scientific literature, however, considers a bioeconomy to be beneficial under stringent social and environmental conditions only. In particular, this concerns sustainable resource use, eco- efficiency and food security, as well as effective governance of the competition between food security and bioenergy [4]. As a general concern, Bugge et al. [44] observe that bioeconomy strategies tend to be driven by the natural and engineering sciences and to lack an advanced socioeconomic understanding and vision. In line with the foregoing, Ramcilovic-Suominen and Pülzl [45] argue that holistic sustainability perspectives, as the integration of social, environmental and economic considerations, have been narrowed down to a supply driven perspective on flows of goods and services and endogenous consumption within the neoliberal paradigm. In particular, the authors note that a more explicit social dimension, including health, labor rights, justice, and culture, as well as intergenerational considerations, is generally lacking from sustainable bioeconomy perspectives. Finally, in a review of modeling studies to assess the relation between the bioeconomy and the SDGs, it is indicated that a bioeconomy may positively contribute to cleaner production technologies, but that socio-economic outcomes are mixed and that environmental targets are generally hurt [1].

The question emerges whether (bio) economic performance can be assessed positively in absence, or at the detriment, of its environmental and social components [1]. After all, an economic transaction is a socially embedded activity whereby matter and energy are transformed to fulfil individual and/or collective needs in society [46]. Hence, economic activity is characterized by social (fulfilment of needs), ecological (impacts of resource use) and technical (the amount of resource use and ecological impacts per unit of desirable output) contingencies and related challenges.

The widely applied three pillar or triple bottom line concept of sustainability recognizes the need for an integrated approach of its social, economic and ecological dimensions. However, its application in sustainability assessments tends to lack a systemic approach of complex contingencies among social and ecological systems [47,48]. Although a recent proposal for a bioeconomy assessment framework focuses on indicators at the intersection of the social, ecological and economic dimension of the three-pillar concept [49], pillars tend to be assessed individually, whereby each dimension can be given greater priority than another [26,50]. In particular, it is argued that economic preferences tend to prevail over other sustainability dimensions [26], with a tendency towards monetary valuation of ecosystem impacts (costs) and social outcomes (benefits) [50]. In the context of bioeconomy strategies, it has been noted that value judgements in high-income countries tend to reflect stakeholder interests within the dominant industrial regimes, thereby marginalizing more ecologically, farmer-based, or 
wellbeing oriented perspectives [43,51-54]. Further, the three-pillar concept of sustainability fails to recognize that bioeconomy contributions such as food, clothes, construction materials and energy are largely substantive in the fulfilment of human needs, meaning that their role and values in society go well beyond monetary indicators. Finally, and based on the foregoing, it can be concluded that the dominant three pillar sustainability concept fails to achieve a comprehensive assessment of the diverse, interrelated and incommensurable impacts and outcomes of a bioeconomy transition in society [1].

An important milestone in contributing to alternative conceptions of sustainability has been the concept of Planetary Boundaries (PBs). In the PB concept, a Holocene-like geological epoch is considered as a biophysical baseline for a livable planet for humanity with respect to (nine) critical environmental boundaries (see Table 1) [55]. At different geographical scales, it has been shown that agricultural and food activities are the main drivers of unsafe levels of land use change (deforestation), water depletion, N \& P pollution, biodiversity loss and global climate warming [18,56,57]. Indeed, understanding the complex interrelatedness of local and global environmental impacts and feedback loops among ecology and society is considered a necessary condition for sustainable bioeconomy transitions [25]. Hence, we argue that bioeconomy strategies need to be designed and evaluated from a coupled social-ecological sustainability perspective.

A growing number of alternative sustainability frameworks take the social and ecological interrelatedness at their core. Building on the concept of safe distances from biophysical limits, Raworth [58] advanced the idea of a social foundation embedded in the biophysical context of the PBs. Raworth's concept of a social foundation involves the fulfilment of fundamental human needs as minimum living standards for the population at large [59], supported by an economic system that operates within ecological thresholds. The current bioeconomy probably is the most important structure in society to support a social foundation and to fulfil individual needs and with 'satisfiers' such as food, medicines, clothes, energy and construction materials, as well as meaningful work and leisure. The centrality of human needs and related concepts of human wellbeing are gaining ground in alternative models for sustainable development [60-62], including degrowth [63,64], as well as in transformative research, for example in relation to energy use [65-67]. In common, these approaches propose to focus on decoupling the satisfaction of human needs from resource use.

Both theory and practice support the existence of a limited number of universal and satiable human needs $[68,69]$. Human needs apply to the individual level, where they are understood to drive actions that sustain the (physical) self, the (social) relation with others, and the (spiritual) relation with the environment [68]. From a eudaimonic perspective, the fulfilment of human needs provides the social and environmental conditions for wellbeing in the broader context of society (as opposed to maximizing pleasure and/or minimizing pain from a hedonistic perspective) [65]. If unsatisfied, human needs should be understood as deprivations that drive individual actions and human development [62]. In this context, the Sustainable Development Goals (SDGs) have been developed as a system of shared societal challenges to end extreme social deprivations (goal 1-6), by developing socio-economic structures (goal 7-12) and by protecting ecosystem functions, in particular biodiversity and the climate system (goal 13-15) [70,71]. As such, the SDG framework provides for a widely agreed, normative direction of equitable development within the biophysical capacity of the planet. This implies an enormous (governance) challenge for high income countries to maintain or improve quality of life, to reduce (total and per capita) resource use and to provide a safe operating space for developing and future populations.

As a bioeconomy transition implies a profound re-coupling of complex social and natural systems in a post-fossil era, a sustainable transition to that end "requires a re-integration of thinking about, analyzing and studying humans as an integral part of the biophysical world" (p. 166, [72]). Furthermore, (bio) economics is challenged to deal with ethical issues such as a fair distribution of scarce biological resources, reduction of overconsumption, and internalization of detrimental social and environmental impacts [73,74]. Hence, we propose a sustainability perspective where a bioeconomy transition can be understood in terms of bidirectional interactions (impacts and feedback effects) among co-evolving 
social and ecological systems in the biosphere. Such a perspective is provided by the lens of coupled social-ecological systems (SES) [31]. The ontological assumption of coupled social-ecological systems implies that (1) humans are fundamentally dependent on the services provided by ecosystems, as well as (2), that humans are a major force in shaping local and global ecosystem dynamics in efforts (strategies) to fulfil human needs and acquire a sense of wellbeing [32] (see Figure 1). An SES-lens is a holistic approach that cannot make explicit distinctions between economic, social, and ecological dimensions of human activity: ecosystems are the source of biogenic materials and energy and, thus, include multiple life forms and physical resources to regenerate human and non-human life [75-77].

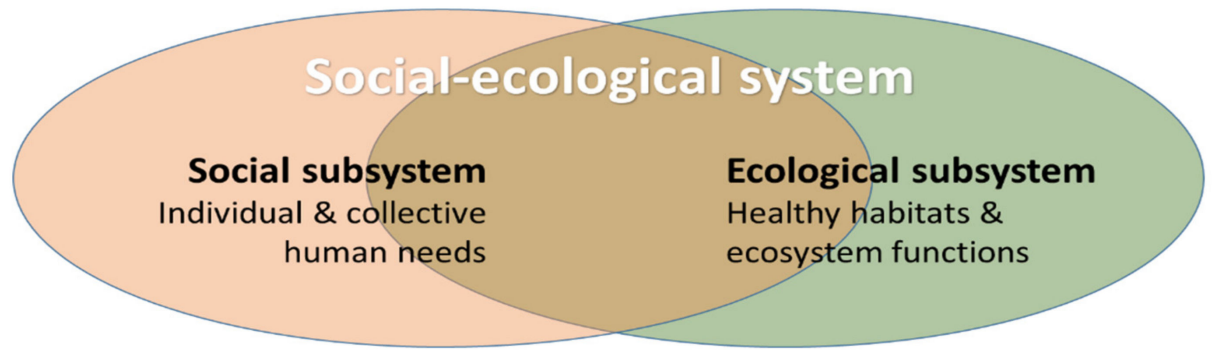

Figure 1. Coupled social-ecological system perspective (based on Berkes, Folke, and Colding [31], Haberl et al. [78] and MEA [32]).

From an SES perspective, it can be argued that human needs have a material dimension, i.e., organic and inorganic substance (materials and energy) from ecological structures (nature), that supports and sustains social structures and physical health. Needs also have a non-material dimension, i.e., the senses, cognition, and autonomy, from which mental products (ideas and actions) emerge as decisions in a coevolving process with the material world (culture) [69,79]. The overlapping social and ecological sphere in Figure 2 reflects the economic appropriation of material structures from nature (resource use) to support the fulfilment of human needs with social structures in society. Production (as an economic activity) is hereby understood as a collective activity (division of labour), satisfying the need for social participation and creation, among others $[68,69]$. As such, the concept of human needs should not be limited to having access to essential products and services (consumption perspective). The fulfilment of human needs also involves the social and politico-institutional decision-making processes that alter (production perspective) and regenerate (governance perspective) social-ecological systems

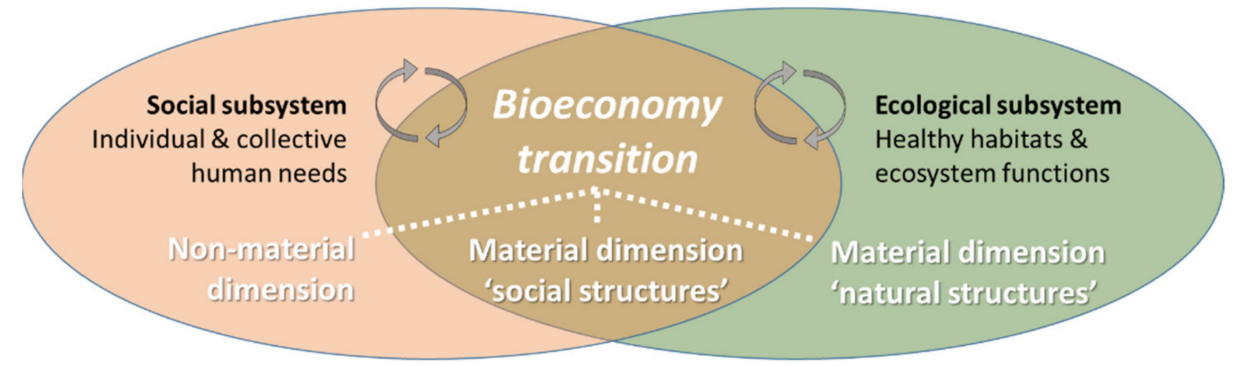

Figure 2. A bioeconomy transition, conceptualized as decision-making processes to fulfil (deprived) human needs with resources from the social and the ecological subsystem (elaborated on $[68,80]$ ). Arrows reflect dynamic and co-evolutionary feedback loops in the coupled SES [33,81].

Human needs are fulfilled by individual and collective strategies, the satisfiers, with varying impact on ecosystem functions, dependent on the scale and intensity of embodied resource use [80,82]. For example, the need for subsistence can be fulfilled with a diet rich in animal protein or rich in plant protein, with a considerable difference in land use, nitrogen pollution, and biodiversity loss. Food choices also involve the choice between unprocessed foods and processed meats, dairy and other perishable, processed foods, where the latter requires considerably larger amounts of energy for 
cooling distribution and storage [83]. The examples indicate that the choice of satisfier provides for individual and institutional decision-making contexts for more, or less, sustainable outcomes at the household, industrial or societal level. In addition, socio-technical alternatives in the production sphere, especially more eco-efficient alternatives, provide for a double dividend of more efficient satisfiers of human needs at the end-user level [65]. Hence, a needs-driven SES perspective contributes to a notion of social-ecological efficiency, i.e., the amount of natural resources and ecological impact associated with preferred satisfiers of (satiable) human needs. Differences in environmental impact in relation to the choice of satisfier to fulfil a satiable need enable "the inclusion of environmental limits and limits to consumption and production activities" [65] without necessarily adverse impacts on human wellbeing. As such, human needs and their satisfiers provide for a context of environmental operating space, responsible decision-making and governance in relation to a SES-based bioeconomy transition. To our knowledge, a needs-driven sustainability approach has not been applied in a bioeconomy transition context, despite the significant role of biobased products and activities in the fulfilment of human needs.

In this section, we advanced an SES-based understanding of sustainability as the capacity of humans to satisfy their needs with strategies that reduce current pressures and impacts on ecosystems. Table 1 provides an overview of underlying concepts and definitions that support such advancement. In the following sections, we will elaborate on needs-driven decision-making contexts as a critical mechanism in bioeconomy transitions from a coupled SES perspective.

Table 1. Overview of key concepts and definitions that support the need for a social-ecological systems perspective on bioeconomy transitions.

\begin{tabular}{|c|c|c|}
\hline Author & Concept & Definition \\
\hline Odum and Odum, 1953, Tilly, 1968 & Ecosystems & $\begin{array}{l}\text { Biological communities of multiple species in some locale, } \\
\text { including the physical and chemical factors and processes that } \\
\text { make up their non-living environment, living in symbiosis and } \\
\text { competition for resources }\end{array}$ \\
\hline Millennium Ecosystem Assessment, 2005 & Ecosystem Services & $\begin{array}{l}\text { Benefits that people obtain from ecosystems. These include } \\
\text { provisioning services such as food and water, regulating } \\
\text { services such as flood and disease control, cultural services } \\
\text { such as spiritual and recreational benefits, and supporting } \\
\text { services, such as nutrient cycling }\end{array}$ \\
\hline Berkes and Folke, 1998, Ostrom $(2007,2009)$ & Social-ecological systems (SES) & $\begin{array}{l}\text { Linked systems of people and nature, where social systems } \\
\text { and ecosystems co-develop and adapt, emphasizing that } \\
\text { humans must be seen as a part of, not apart from, nature }\end{array}$ \\
\hline Rockström et al. 2009 & Planetary Boundaries & $\begin{array}{l}\text { Global limits to human perturbation of nine dynamic and } \\
\text { interrelated earth-system processes i.e., climate change, } \\
\text { biodiversity loss, biogeochemical flows, ocean acidification, } \\
\text { land system change, fresh water use, stratospheric ozone } \\
\text { depletion, atmospheric aerosol loading, and chemical } \\
\text { pollution and release of novel entities, that mark out a 'safe } \\
\text { operating space' for humanity }\end{array}$ \\
\hline Max-Neef, 1991, 1992 & Fundamental Human Needs & $\begin{array}{l}\text { A system of } 10 \text { fundamental human needs, i.e., subsistence, } \\
\text { protection, affection, understanding, participation, leisure, } \\
\text { creation, identity, freedom, and transcendence, that can be } \\
\text { sensed as deprivations (poverties) and as drivers of needs } \\
\text { satisfaction (development) }\end{array}$ \\
\hline
\end{tabular}

\section{Understanding Bioeconomy Transitions through a Social-Ecological Systems Lens}

In order to better understand the mechanisms that drive and sustain social-ecological systems in relation to (potential) bioeconomy transitions, we review distinct, yet related, strands of SES-literature. First, we apply the ecologically oriented SES (eco-SES) perspective $[31,33,84]$, which focuses on the functioning of ecosystems in response to anthropogenic perturbations. Second, we look at bioeconomy related activities from the socially rooted SES (soc-SES) perspective [34,85]. The soc-SES perspective unravels emerging and self-sustaining governance systems for sustainable use of natural resources in collective resource use systems (the commons). Third, we review the telecoupling (SES) literature in relation to bioeconomy, which can be applied to analyze outcomes and impacts of changes in social-political institutions within and among SESs at the macro/global level of the resource 
system [36,37]. In absence of a dedicated SES-literature on bioeconomy transitions, we based our search on a selection of peer-reviewed case studies in agriculture, food and bioenergy contexts, as well as more integrated studies of rural SESs.

\subsection{Ecologically Oriented SES Perspective}

The ecologically oriented SES ("eco-SES") perspective on bioeconomy transitions highlights the biophysical dimension of human-nature interactions, as an indicator of the scale and intensity of resource use and related ecological impacts to fulfill human needs, in particular, physical health. Ecological systems-or ecosystems - are now commonly understood as open systems of symbiotic and competing populations in their habitat, including energy and matter $[86,87]$. Perturbations of ecosystem functions can be triggered by overexploitation and/or pollution of the resource base, for example in relation to agriculture and other bioeconomy activities at the local level of the global land system. Critical (severe) perturbations may trigger non-linear responses and self-organization towards new ecosystem structures with altered system functionalities that may affect multiple levels in the biosphere, i.e., from gene level to organisms, populations, species, ecosystems or whole biomes $[33,84,88]$. Ultimately, ecosystem functions may be altered to an extent that humans can no longer coevolve [89], for example in a process of desertification as a result of unsustainable water use in agriculture [90].

The eco-SES lens can be applied from both an internal and an external system perspective. From an internal eco-SES perspective, humans are considered part of the biosphere and need to sustain and reproduce themselves with food and other life sustaining consumption activities such as energy for heating, construction materials for housing, clothes for protection, and medicines and fresh water, among others. Through bioeconomy activities, humans act as heterotroph predators in the food web, where their increasing number and rising animal and fish consumption levels prove to be a severe threat (pressure) for biodiversity (impact) and the resilience and sustainability of a growing number of local SESs worldwide [37,91,92].

From the external eco-SES perspective, bioeconomy activities cause production related pressures on the regenerating and waste assimilating capacities of the functional layers in the biosphere. In efforts to increase production and yields in the bioeconomy, humans artificially alter the functioning of food webs and ecosystems by, among others, the application of fertilizers and pesticides, as well as by indirect adverse impacts on soil erosion and biodiversity loss [18]. For example, the persistence of neonicotinoids (insecticide) in soils and water ways has provided pathways of perturbation that can affect the fertility of pollinators, with cascading effects on a range of ecosystem services [93]. Here, a bioeconomy transition can be understood as external perturbations of social-ecological systems, thereby threatening the resilience of life supporting ecosystem functions such as climate stabilization, water storage, nutrient cycling, and biodiversity and, hence, the sustainability of the SES from the local to the global level $[32,47]$. Both from an internal and external eco-SES perspective, however, it should be noted that a bioeconomy transition can also reduce impacts and related feedback loops, both as a result of more responsible consumption and production activities [94], and in terms of rewilding as ecological succession states in response to land abandonment [95].

\subsection{Socially rooted SES Perspective}

From a social perspective, SES research is rooted in resource use problems and overpopulation $[85,96]$. More specifically, a social dilemma between self-interest and the public good exists regarding the use of shared resources such as groundwater, fish stocks and the climate system, which ends up being overexploited with detrimental effects for both the individual and the collective. 'Governing the Commons' by Ostrom (1990) provides evidence for the capacity of actors to produce self-organized institutions that prevent detrimental ecological degradation, which added a meaningful middle road to the dichotomy between proponents of government-imposed protection and privatization of common pool resources [97]. Ostrom's SES framework is increasingly applied to gain knowledge and advance understanding of factors 
that affect the likelihood of self-organization by resource users, including the size and productivity of the resource system and the predictability of system dynamics [98,99]. By relating resource use problems to theories in both economics (bounded rationality) and ecology (multi-level structures and processes in the organization of living systems), complex social-ecological systems can be deconstructed and institutions understood as emergent properties based on collective agency of actors $[34,85,100]$.

The soc-SES lens articulates agency with respect to resource use and social reproduction in the territorial context. This indicates the need for individual and collective capabilities to develop institutions that support sustainable outcomes in the (increasingly global) resource system. As a bioeconomy largely consists of agriculture and forestry, farms and their management decisions generally are at the center of the territorial resource use system [101]. Farming is among the most direct form of human-nature interaction, as agricultural inputs are added to the soil, products are directly harvested from the-managed-ecosystem, and the majority of farmers depend on ecosystem functioning for their income. From a (rural) socioeconomic perspective, however, the hierarchically structured social subsystems of the SES are also defined at the municipal level, where people feel the strongest place attachment with agriculture, forestry, and tourism, among others [102]. From this place-based perspective, governance of common SES resources is not only pivotal to sustain their material functions (commons), but is also central in the social, non-tangible, reproduction of the community. For example to provide a space for recreation and leisure, to share culture, to support learning, or to take care of each other (commoning) [103].

The current wave of bioeconomy strategies is supported by institutional incentives to engage new, mainly industrial, actors in the resource system $[9,40]$. Stakeholders from, among others, chemical, pharmaceutical, construction, manufacturing and health industries are exploring opportunities for the replacement of fossil by biobased refineries and related technologies, which may speed up changes in the number and type of resource users, the demand for non-food biomass, as well as infrastructure, industrial processes, and production sites in rural and urban-rural socioeconomic systems $[104,105]$. These-potentially disruptive-changes have uncertain impacts on the resource system, social equity and climate resilience in the generally culturally rooted and co-evolved SES in rural areas [102]. From a governance perspective, the revised EU bioeconomy strategy addresses the need for multi-level participation of member states, regions and cities in bioeconomy strategies, a better alignment of different policy fields, as well as active support for the deployment of inclusive local bio-economies in rural areas [43]. The soc-SES perspective on bioeconomy transition processes highlights the importance of multi-level and multi-actor governance for a sustainable reproduction of social-ecological systems [103].

\subsection{Telecoupling SES Perspective}

In a globalized world, SES dynamics are seldom limited to the territorial context. Liu et al. (2007, 2013) integrate various socioeconomic and social-ecological interactions in a spatially distributed SES-network. These so-called telecouplings show to emerge from agents that facilitate or hinder the flows of material, energy and/or information among SESs, thereby referring to the agency in Ostrom's SES framework and grounding the framework in the social realm [37]. However, instead of assuming a complex relation between individual agency and emergent collective behavior, the telecoupling framework builds on Foucauldian power relations and world systems theory [106], aiming to contribute explanatory variables of inequalities and justice issues between focal and peripheral SESs in the global resource system [107]. As such, the telecoupling perspective takes the territorial SES perspective to the global level, with multiple interactions and feedbacks among SESs.

From the telecoupling SES perspective, case studies show how commodity trade and changes in food and trade regulations result in unequally distributed impacts of land use and biodiversity loss, among others $[37,108,109]$. For example, telecouplings involve the increase in maize as a second crop in the Brazilian Cerrado, in response to China's growing demand, thereby increasing the vulnerability of Brazilian farmers for extreme climate events [110]. As land use change and biodiversity loss are 
among the most critical impacts in life support systems provided by the biosphere, the telecoupling perspective indicates the risk of an unjust distribution of impacts of bioeconomy transitions among SESs. However, applying the telecoupling framework as an analytical tool in the global resource system, with its multiple actors, sectors, outcomes and impacts, is complex and probably most feasible in relation to specific research questions and related boundary choices [111], for example to shed light on the complex relation between non-food bioeconomy pathways in high-income countries and food security in low income countries or regions.

\subsection{Summary of SES Perspectives on Bioeconomy Related Activities}

Table 2 summarizes critical human-nature interactions in the resource system, associated with bioeconomy activities from the different SES (literature) perspectives (1st column). The summary is not exhaustive but serves to highlight the systemic relation between systemic drivers of resource use, impacts on ecosystem functions, and feedback loops among social and ecological systems. It can be concluded that decision-making for a sustainable bioeconomy transition implies responsible consumption as a condition for physical health of humans and ecosystems, responsible production to reduce artificial inputs and waste flows, and social-ecological reproduction as a common and shared responsibility to sustain ecosystem functions (most right column in Table 2).

Table 2. Summary descriptions of (main) critical human-nature interactions in relation to bioeconomy activities in high income country contexts, from an ecological (Eco-SES), social (Soc-SES), and telecoupling (Tele-SES) perspective.

\begin{tabular}{|c|c|c|c|c|}
\hline SES Perspective & $\begin{array}{l}\text { Systemic Drivers of } \\
\text { Resource Use }\end{array}$ & $\begin{array}{l}\text { Environmental Pressures \& } \\
\text { Impact }\end{array}$ & $\begin{array}{l}\text { Social-Ecological Feedback } \\
\text { Loops }\end{array}$ & Decision Making Context: \\
\hline \multirow[t]{2}{*}{$\begin{array}{c}\text { Eco-SES } \\
\text { (biophysical } \\
\text { perspective) }\end{array}$} & $\begin{array}{l}\text { High levels of resource } \\
\text { intense satisfiers in high } \\
\text { income countries (animal } \\
\text { products, bioenergy) }\end{array}$ & $\begin{array}{l}\text { Humans as heterotroph } \\
\text { top-predators in the food } \\
\text { web, impacting biodiversity } \\
\text { and the climate system at } \\
\text { multiple levels in the } \\
\text { biosphere }\end{array}$ & $\begin{array}{l}\text { Overconsumption of food } \\
\text { and energy (overweight, } \\
\text { obesity) threatens human } \\
\text { health and ecosystem } \\
\text { resilience in a growing } \\
\text { number of SESs worldwide }\end{array}$ & $\begin{array}{l}\text { Responsible } \\
\text { consumption/Physical } \\
\text { health: } \\
\text { Humans, as heterotroph } \\
\text { ecosystem species, need to } \\
\text { reduce competition for } \\
\text { energy, materials, and } \\
\text { nutrients with non-human } \\
\text { organisms }\end{array}$ \\
\hline & $\begin{array}{l}\text { Technology as an artificial } \\
\text { enhancer of ecosystem } \\
\text { provisioning function, } \\
\text { driving scale enlargement } \\
\text { and loss in crop diversity } \\
\text { (animal feed, biorefinery) }\end{array}$ & $\begin{array}{l}\text { Mechanization, fertilizers } \\
(\mathrm{N} / \mathrm{P}), \text { pesticides, and waste } \\
\text { flows, among others, } \\
\text { affecting soil functions, } \\
\text { bio-diversity, and the } \\
\text { climate system }\end{array}$ & $\begin{array}{l}\text { Path dependencies between } \\
\text { capital intensive } \\
\text { mechanization, industrial } \\
\text { scale, and ecosystem } \\
\text { degradation, with systemic } \\
\text { feedbacks among } \\
\text { agriculture, food, } \\
\text { biodiversity, and the climate } \\
\text { system }\end{array}$ & $\begin{array}{l}\text { Responsible production: } \\
\text { Creativity and participation } \\
\text { to reduce levels of artificial } \\
\text { enhancers (inputs) and } \\
\text { waste flows (outputs) as } \\
\text { external pressure/stressor of } \\
\text { ecosystem functions }\end{array}$ \\
\hline $\begin{array}{c}\text { Soc-SES } \\
\text { (social perspective) }\end{array}$ & $\begin{array}{l}\text { Farm-centered governance } \\
\text { and self-organisation to } \\
\text { sustain multi-functional SES } \\
\text { resources as "commons" }\end{array}$ & $\begin{array}{l}\text { Top-down gover-nance (e.g., } \\
\text { energy directive) and novel } \\
\text { industrial agents change and } \\
\text { poten-tially disrupt } \\
\text { micro-level governance for } \\
\text { social-ecological } \\
\text { reproduction }\end{array}$ & $\begin{array}{l}\text { Capitalist and non-capitalist } \\
\text { governance structures } \\
\text { support and affect } \\
\text { reproduction capabilities of } \\
\text { SES agents [103], with a } \\
\text { distinct difference in SES } \\
\text { resilience }\end{array}$ & $\begin{array}{l}\text { Social-ecological } \\
\text { reproduction: } \\
\text { Agency and shared } \\
\text { responsibility to sustain } \\
\text { ecosystem functions as a } \\
\text { condition for } \\
\text { social-ecological } \\
\text { reproduction }\end{array}$ \\
\hline $\begin{array}{c}\text { Tele-SES } \\
\text { (politico-institutional } \\
\text { perspective) }\end{array}$ & $\begin{array}{l}\text { Hegemonic trade regimes } \\
\text { accumulate cost-efficient } \\
\text { biomass commodities at } \\
\text { focal-SES }\end{array}$ & $\begin{array}{l}\text { Ecologically unequal } \\
\text { exchange among SESs in } \\
\text { terms of land use change, } \\
\text { water pollution, biodiversity } \\
\text { loss \& climate change, } \\
\text { among others }\end{array}$ & $\begin{array}{l}\text { Environmental degradation } \\
\text { increases social } \\
\text { vulnerabilities in low } \\
\text { income SESs and obstructs } \\
\text { autonomy to protect } \\
\text { ecosystems. Increased risk of } \\
\text { adverse SES feedback loops }\end{array}$ & $\begin{array}{l}\text { Trade and (global) } \\
\text { governance/justice: } \\
\text { Institutions to prevent unjust } \\
\text { impacts of bioeconomy } \\
\text { activity among SESs in the } \\
\text { global resource use system }\end{array}$ \\
\hline
\end{tabular}




\section{A Place-Based BIO-SES Framework to Support Sustainable Bioeconomy Transitions}

Based on insights into critical human-nature interactions and relevant decision-making contexts of a bioeconomy transition from an SES-perspective (Section 3), this section constructs a framework to support the formulation, monitoring, and evaluation of coupled social outcomes and ecosystem impacts as distinct steps in the bioeconomy transition process. Following from the telecoupling SES perspective, which emphasizes detrimental impacts and feedback effects among micro-level SESs in the global resource use system, the framework extends the traditional territorial SES boundaries towards a global resource use (footprint) perspective, yet from a place-based perspective. Place-based refers to the cultural roots of bioeconomy agents in an ecologically delineated territory, i.e., a geographically defined population that evolves in a dynamic relation with its ecological context [101]. Furthermore, it refers to economic activity as the product of various flows across space and time that intersect and generate unique structures of extraction, production and consumption activities in the global resource system, i.e., a spatial economic perspective [112]. As such, the place-based perspective includes trade-flows and related impacts, highlighting the mechanism whereby bioeconomy activities (meso-level) connect human needs and social outcomes (micro-level) with impacts in the global resource system (macro-level). With a place-based perspective, the framework aims at making stakeholders aware of the complexity of a place-based bioeconomy transition in the globally shared resource system, yet at the same time providing a tool to support responsible, evidence-based decision-making towards desirable social outcomes from an SES-based sustainability perspective.

Figure 3 outlines a prototype of the place-based BIO-SES framework, distinguishing the social sub-system (in orange), the ecological sub-system (in green), as well as the (coupled) resource use activities (in brown) associated with a place-based bioeconomy transition. The prototype takes a matrix structure of the needs-driven decision-making contexts (responsible consumption, responsible production, and social-ecological reproduction) in rows, and links them to social outcomes, embodied resource use and related ecosystem impacts in columns. From left to right, the framework reads as (deprived) human needs driving decision-making towards social outcomes and ecological impacts of consumption, production and reproduction activities in the global biosphere. On the one hand, the framework has an exploratory character as it supports an (ex-ante) evaluation of ecosystem impacts as a function of consumption and (re)production strategies to strengthen the social foundation in society. On the other hand, it supports evaluative capacities of stakeholders to analyze and understand impacts of bioeconomy strategies in the global resource system.

With reference to different classes of SES based frameworks [113], the proposed BIO-SES framework conceptualizes the relationship between the social and the ecological system as bidirectional, takes an anthropocentric perspective on changes in ecosystem functioning, and is both analysis- and action oriented. As with Ostrom's SES-Framework, the BIO-SES framework discerns a resource system (land), resource units (biomass, water, energy, ... ), resource users (farmers, industries, households, ... ) and a resource governance system (conditions and capacities to sustain a social-ecological reproduction of the place-based system). Expanding on Ostrom's conception, the BIO-SES framework also takes a global (as compared to a local) resource system perspective, which includes traded materials and energy from and to other SESs in the global resource system. The latter implies extending the concept of direct resource users [114] towards any intermediate or final consumer of biobased resources (agent) in the place-based system. In line with recommendations to better integrate the ecological dimension in Ostrom's socially rooted SES-Framework $[115,116]$, the prototype emphasizes the need for a more explicit accounting of ecological impacts associated with place-based economic activities in the global resource system. This is particularly relevant for the identification of harmful telecouplings in the global land system, induced by resource use of the place-based SES [117]. Identifying these impacts is an important framework application and needs to feed in the evaluation process of a bioeconomy transition. 
The BIO-SES framework aims at advancing awareness and understanding of how alternative consumption and production strategies at the territorial level change social outcomes and ecosystem impacts at the global level. To this end, a quantitative baseline assessment of current resource use and ecosystem impacts embodied in strategies to fulfil the needs of the place-based population shall be the starting point of a bioeconomy transition process. From there, alternative strategies (scenarios) can be explored, monitored and evaluated. For example, reducing the amount of animal-based protein products could support human health and reduce ecosystem impacts associated with food consumption in high income countries. From a production perspective, and depending on the ecological context, bioeconomy stakeholders could opt to shift from animal feed and livestock production towards forestry and wood-based activities, for example to replace fossil resources in the construction and housing sector. Altered consumption and production patterns, technical and social innovations and new job opportunities can support the place-based population to become more social-ecologically efficient, i.e. a bioeconomy strategy that fulfills the needs of a SES-based population with lower levels of resource use and ecosystem impact in the global resource system. 


Social system $\quad$ Resource use

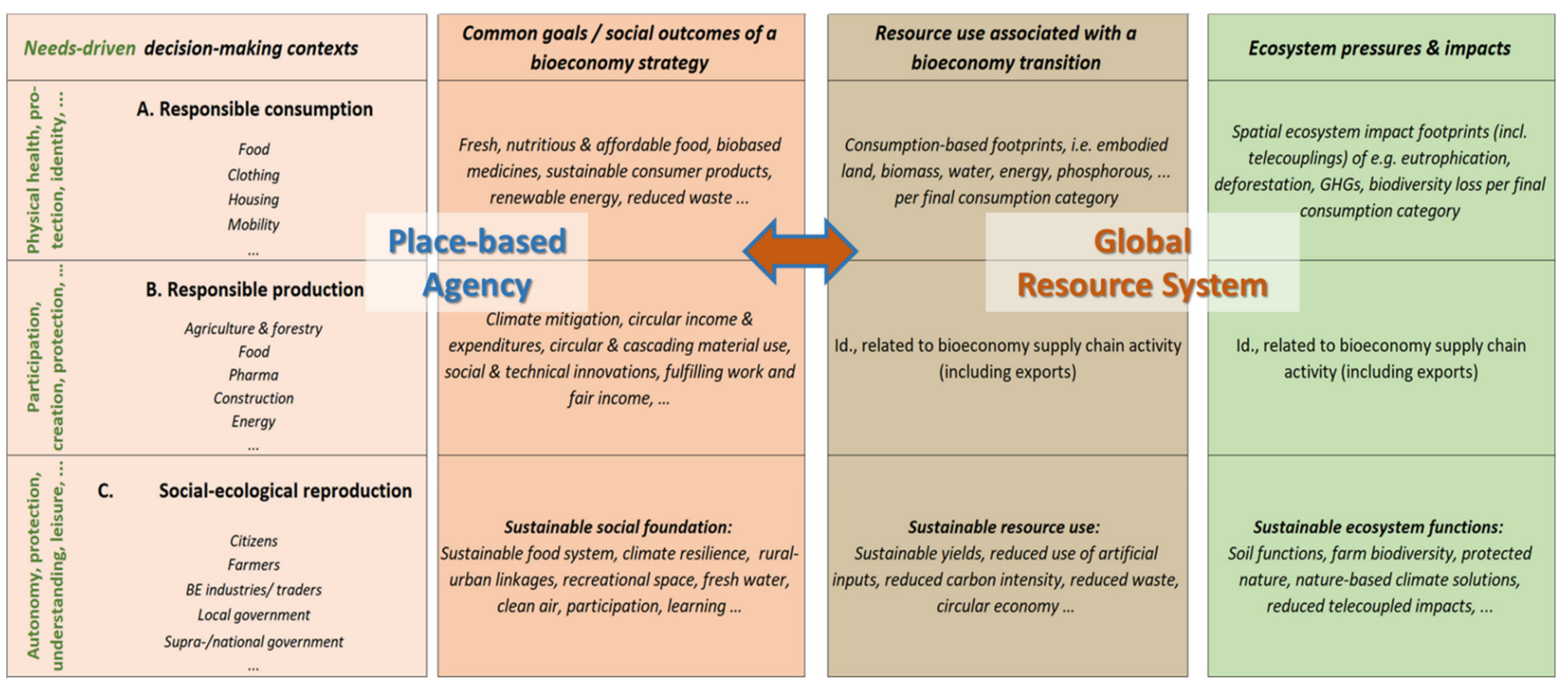

Figure 3. Prototype of the BIO-SES framework to define, monitor and evaluate outcomes and impacts of place-based bioeconomy transitions in the global resource system (based on Ostrom [34], Raworth [58], Duchin [118]). 
To be able to understand and evaluate social and technological progress in terms of changes in ecological pressures and impacts, there is a need for a detailed, and preferably dynamic, account of inter-industry use and supply of biobased resources (footprints) in the global resource system. This would require robust economic database construction at sub-national levels [119], thereby benefitting from life cycle and material flow analysis [120]. Hence, overcoming methodological issues to provide a comprehensive set of robust databases covering multiple scales in the global resource system is pivotal for providing an adequate evidence base for effective governance systems. Such a detailed account can help in identifying (responsibility) hotspots of ecosystem impacts related to specific economic activities in the place-based system, as well as improvements (reductions) associated with socio-technical alternatives $[118,121]$.

Applying the BIO-SES framework in the multi-agent, multi-sector setting requires a participatory evaluation of outcomes and impacts in an iterative adjustment process [122] (Figure 4 and Section 5). Iterative bioeconomy strategy adjustments can support the transition process towards (more) responsible consumption, production and social-ecological reproduction activities in high-income country contexts.

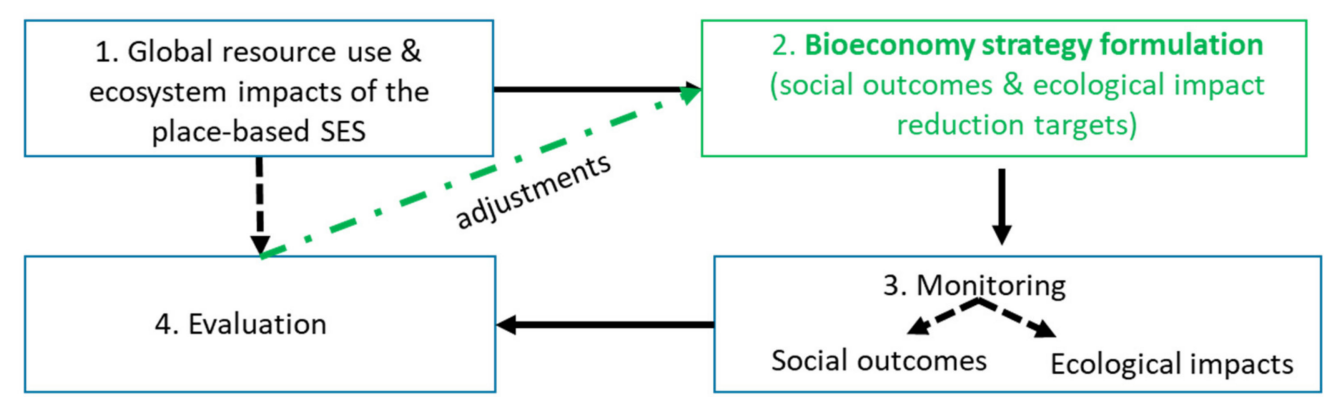

Figure 4. Iterative monitoring, evaluation and adjustment process of a bioeconomy transition in the place-based SES.

\section{Synergies in SDG-Aligned Bioeconomy Transitions}

Understanding bioeconomy transitions as place-based change processes towards different potential outcomes does not automatically result in a 'degrowth' direction of resource use and related impacts in high income country contexts. The concept of human needs, satisfied by a large number of bioeconomy related products and resources, proves challenging to apply as a normative guiding for sustainable bioeconomy transitions [123]. Human needs drive decision-making at the individual level, where it is assumed that a deprivation (unfulfilled needs) drives both autonomous (internal) and cognitive (externally driven) sense-making processes towards action [124]. To use needs as a driver for responsible decision-making in a bioeconomy context thus implies the existence of, and agreement on, collective deprivations that can be solved by a bioeconomy strategy. Three bioeconomy-related deprivations stand out in high income country contexts: overconsumption (dis-satisfier for human health), degradation of (telecoupled) ecosystems, and growing inequalities in the rural-urban context [43,49]. A bioeconomy strategy can very well be designed to end such deprivations but, so far, neither collective deprivations nor comprehensive monitoring systems to that end, i.e., including consumption-based perspectives, have been consistently taken into the formulation, monitoring and evaluation process of bioeconomy strategies.

In order to strengthen the sustainability potential of a place-based bioeconomy strategy, i.e., the fulfilment of collective needs (commons) while reducing environmental pressures, we propose to align the BIO-SES framework with the UN agenda to achieve the SDGs by 2030. The other way around, framing the SDGs in the BIO-SES framework provides for normative decision-making contexts and targets aiming at solving societal problems or creating societal opportunities with a place-based bioeconomy strategy. Implementing an SDG-aligned BIO-SES framework emphasizes the role and responsibility of high income countries to act on the relation between food and non-food bioeconomy 
outcomes and impacts: environmental operating space for non-food bioeconomy activities to help to achieve the SDGs needs to be supported by shrinking operating space for the food-related bioeconomy in high-income country contexts. As food, and in particular animal based food, in the majority of high income countries is culturally rooted, such a transition would require measures in several policy fields, including agricultural and social policy, to coordinate a (humane) transition from livestock towards more plant and/or nature based climate solutions. Furthermore, ongoing urbanization increases the multi-facetted (governance) challenge for cities and communities to develop sustainably (SDG11), both in high and low income countries, in particular with respect to the dependency of cities on rural areas and their communities. Hence, bioeconomy transitions embody opportunities to create short, circular and sharing networks for both social and technical innovations (SDG 8,9) at the sub-national level of society, in particular among rural and urban communities (SDG 10,11). Similarly, efforts to frame community based bio-energy as a "common", and make communities aware of a shared deprivation and goal (clean energy), has proven to support social innovation, investments and related spillovers to mitigate climate change in rural regions (SDG7, 13) [125].

Furthermore, and most importantly, linking bioeconomy transitions with the SDGs provides for synergies and efficiencies in the governance ("how to get from A to B") of hierarchically structured social systems on the basis of contextualized responsibility and capacity to act in the global resource system. Linking bioeconomy strategies with the SDGs is likely to shift or complement market oriented governance efforts towards more differentiated, place-based opportunities and responsibility. The principle of "Common but Differentiated Responsibility (CBDR)" emerged in the context of the Rio Declaration in 1992, whereby industrialized nations would take the lead in addressing the "common" goal of climate stabilization [126,127]. The principle, grounded in notions of fairness and capacity to act [126], has been translated into development-aligned concepts of contraction (of footprints) and convergence (of societies' wellbeing) in relation to the planet's biocapacity [128]. CBDR has also been articulated as a governance approach for sustainable development, where it has been shown that multi-level, administrative policy measures have been complemented and contextualized by marketand network-based governance approaches $[129,130]$. Similar levels of complexity can be assumed with respect to the governance of sustainable bioeconomy transitions in society [131], articulating the need for place-based approaches to shape "reflexive governance in a decentralized political environment, creating co-operative civic participation and state-engagement"(p. 601, [132]).

In high income countries, place-based industrial policy approaches have been proposed as strategies for industrial policy $[133,134]$. Referring to heterogeneity in political, cultural, and institutional contexts, a context contingent strategy for place-based development is proposed to "reduce persistent inefficiency (underutilization of the full potential) and inequality (share of people below a given standard of well-being and/or extent of interpersonal disparities) in specific places, through the production of bundles of integrated, place-tailored public goods and services, ... " (p.17, [133]), [135]. From the perspective of coupled social-ecological systems, it can be argued that responsible production in the bioeconomy needs to develop in line with the ecological context, e.g. wood-based bioeconomy strategies in forest-rich contexts, biofuels in regions suitable for maize, and nature-based climate solutions in mountainous areas. Furthermore, in building more circular, cascading and low carbon economic systems, place-based governance of bioeconomy transitions needs to reconcile context contingent production strategies with horizontal consumption networks at the regional level, in particular in the urban-rural context. In other words, governance of bioeconomy transitions in the globally shared resource system actualizes place-based responsibilities in a context of vertical (multi-level) and horizontal (multi-SES) coordination [133].

Although it is beyond the scope of this paper to elaborate on (meta) governance for sustainable bioeconomy development, we consider it important to highlight the potentially strong synergies when aligning bioeconomy strategies with the SDGs. For example, SDG 1 and SDG 2 emphasize environmental sustainability as a policy objective in eradicating poverty and ending hunger, which implies a strong role for agricultural policy and related policy fields [136,137]. SDG 11 (sustainable cities and communities) 
includes targets for a participatory governance approach towards sustainable resource use, including land, thereby emphasizing governance systems for sustainable urban-rural linkages in a bioeconomy transition. Stronger urban-rural linkages have also been emphasized as a key mechanism to achieve sustainable food systems in the context of SDG 2 [136]. SDG 12 requires "a strong national framework for sustainable consumption and production that is integrated into national and sectoral plans, sustainable business practices and consumer behaviour, together with adherence to international norms on the management of hazardous chemicals and wastes" (https://sustainabledevelopment.un.org/sdg12). Considering the overconsumption of resource intensive animal products, biodiversity loss in relation to nitrogen and phosphorous pollution, and the excessive amount of food related waste, national and sub-national food strategies in high income countries are likely to become governance hotspots for achieving both sustainable bioeconomy transitions and SDG12. With respect to life on land (SDG 15), strong synergies exist in the monitoring and evaluation of territorial ecosystems, for which a participatory monitoring and iterative adjustment approach has been proposed in the context of achieving the SDGs [125]. Figure 5 indicates potential synergy hotspots for SDG-aligned governance efforts in the context of a bioeconomy transition process.

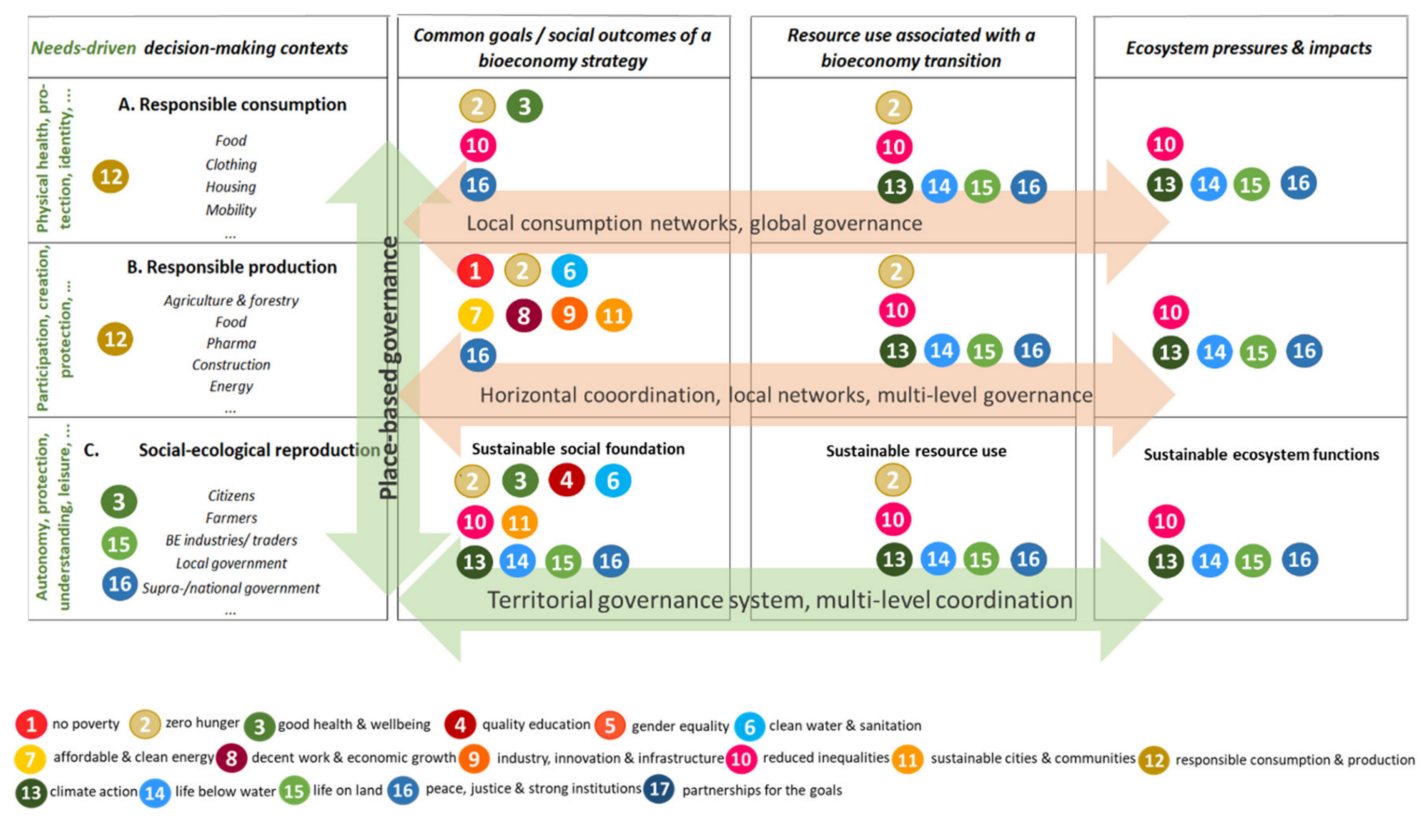

Figure 5. Potential synergies in governance efforts to achieve the SDGs with place-based bioeconomy strategies (arrows indicate the scope and direction of the governance structure, colours refer to territorial/place-based (green) and market oriented (orange) coordination in the governance system).

Real synergies of SDG-aligned bioeconomy strategies would largely depend on ex-ante agreed goals and outcomes of a bioeconomy transition process at the SES level. Case studies of place-based bioeconomy activities indicate that engagement through participatory processes and responsibility for social outcomes are positively correlated with stakeholder awareness and public trust [122,125]. Furthermore, as highlighted by the BIO-SES framework in Section 4, a sustainable bioeconomy transition process requires a comprehensive systems approach of coupled social outcomes and ecological impacts (evidence base) to make stakeholders aware of the impacts of their actions in the global resource system. This includes a quantitative perspective on hotspots of spatial ecosystem impacts associated with place-based consumption and production activities [23,138], capacities of the social system to (collectively) evaluate impacts associated with social outcomes (reflexivity) [122,135], as well as the capacity to create enabling and constraining governance structures for SDG-aligned bioeconomy strategies from a high income responsibility perspective $[129,131]$. 


\section{Conclusions and Recommendations}

In the context of climate change, the current wave of bioeconomy strategies indicates a potential transition from fossil to biobased carbon in economic structures worldwide. However, considering that many of the planet's most critical environmental impacts are associated with food- and energy related bioeconomy activities, it can be inferred that the environmental operating space for expansive non-food bioeconomy strategies is limited. For low income countries, with lower than average resource use levels, this implies a complex challenge as bioeconomy is the most important social structure and economic activity to fulfil fundamental human needs with substantive products and services. For high income countries, with relatively high levels of resource use and ecosystem impacts, we have argued that increased use of biobased resources for non-food purposes would need to be accommodated by a reduction of food related impacts in the global resource system. Reducing environmental pressures and impacts by high income countries is important in order not to impede the capacity of others to fulfil their needs ("just") with strategies that are contingent on ecosystem functions provided by the biosphere ("safe"). To support a bioeconomy transition process towards reducing current environmental impacts, yet identifying development opportunities in the place-based context of social-ecological systems, we have presented a novel framework. The BIO-SES framework supports the formulation, monitoring, and evaluation of common social outcomes and reduction of ecosystem impacts associated with place-based bioeconomy strategies in the globally shared resource system.

In order to ground the framework in the complex problem of planetary boundaries, we applied an ontological lens of coupled social-ecological systems (SES) and explored critical human-nature interactions related to bioeconomy activities. The SES-lens provided insights on critical mechanisms among social and ecological subsystems of the SES in response to bioeconomy activities. Based on our explorations, it has been shown that a sustainable bioeconomy requires (1) responsible consumption as a condition for physical health and biodiversity in the shared biosphere, (2) responsible production to reduce artificial enhancers (inputs) and waste flows (outputs) of economic systems, and (3) autonomy and capacity for self-organisation to protect ecosystem functions and humans' dependency thereof (social-ecological reproduction). Based on these insights, we developed the prototype of an SES-based monitoring and evaluation framework, which' application can support an integrated assessment of social outcomes and ecological impacts of bioeconomy strategies from a place-based perspective. Hence, the SES-perspective challenges agents in high income country contexts to make best efforts in developing bioeconomy strategies that reduce current levels of embodied resource use and related impacts, when working towards achieving social outcomes. For example, replacing fossil by biobased plastics would need to be accompanied by a reduction in environmental impact, in particular GHG emissions, land use and phosphorous and nitrogen pollution footprints in the global resource system.

Applying the SES lens contributes to a more holistic understanding of the contingent and dynamic relation between social and ecological systems, as compared to the balanced equilibrium of social, economic and ecological sustainability in the three-pillar concept of sustainability. The BIO-SES framework takes an interdisciplinary perspective by considering that human needs, social outcomes and environmental impacts are intrinsically linked. With reference to different classes of SES based frameworks [113], the BIO-SES framework conceptualizes the relationship among social and ecological systems as bidirectional, takes an anthropocentric perspective on changes in ecosystem functioning, and is both analysis- and action oriented.

As human needs apply at the individual level, place-based populations may struggle to identify and formulate common outcomes and become vulnerable to dominant or new industrial interests in the place-based resource system. Aligning the BIO-SES framework with (selected) SDGs may overcome a potential lack of common outcomes and direction of bioeconomy transition processes, as synergies exist in identifying common outcomes, in monitoring the resource system and in governance structures to achieve common goals. With respect to the latter, it is indicated that SDG-aligned bioeconomy strategies may shift the market orientation towards a more differentiated form of place-based responsibility in the global resource system. The latter is likely to benefit from a participatory formulation, evaluation, and 
adjustment process of bioeconomy strategies, thereby using the BIO-SES framework as a contextualized monitoring system to strengthen self-organisation and reflexivity in the social system. In the context of the transition towards low carbon, biobased and circular economic systems, and considering the need to reduce resource use and related impacts by high income countries, SDG-aligned bioeconomy outcomes are most likely to emerge at the sub-national level of society. At the sub-national level, a multi-sector perspective can support social and technical innovations in multi-actor networks of urban and rural communities [139]. Highlighted in the literature, multi-actor engagement is among the most challenging, yet critical, aspects of successful governance of natural resources and dependent on human resources and funding [140].

Although developed to advance place-based responsibility of bioeconomy transitions in high income country contexts, the framework can also be advanced for needs-based bioeconomy transitions in low or middle income country contexts. However, population growth, the lack of consistent environmental databases and a reference level for environmental impact (outer boundary), will add to the complexity in the evaluation process and related governance system. On the other hand, advancing and applying the framework in developing country contexts is likely to show the necessary resource use associated with increases in wellbeing in developing country contexts, thereby adding urgency to reduce resource use and related impacts in high income country contexts.

We can conclude that, at this point in the "bioeconomy transition movement", the lack of empirical evidence and robust social-ecological theory prevents a clear answer to the question if and how bioeconomy transitions in high-income country contexts contribute to sustainable development. However, we have argued that sustainable bioeconomy strategies depend on appropriate sustainability frameworks to make agents in place-based systems aware of, and responsible for, the critical and interdependent relation of social and ecological systems in the global resource system. Hence, the proposed BIO-SES framework is an interdisciplinary assessment tool, which can be applied and further developed in the empirical context of place-based bioeconomy transitions. With SES-based bioeconomy assessment frameworks, a case study database of place-based bioeconomy transitions can be constructed and serve as a learning environment for the development of robust social-ecological theory on the role, impacts and governance of bioeconomy transitions in society.

As to the question of how to monitor and evaluate bioeconomy transitions, the BIO-SES framework fills an important research gap by providing an outline for a comprehensive, yet spatially explicit monitoring and analysis of bioeconomy transitions in terms of coupled social outcomes and ecological impacts in the limited biosphere. Comprehensive database development in this context is of utmost importance, as the ontological approach is strongly dependent on the availability and quality of timely updated databases of both economic activity and the state of ecosystems in the global biosphere. At the sub-national level, database construction can also become a participative effort and a place-based responsibility in local governance of the global resource system.

Author Contributions: L.d.S. prepared the original draft including literature review, framework conceptualization, figures, and writing. S.G. supervised and supported all research stages, and edited and commented on the article. T.H. provided guidance in the conceptualization and narrative of the article and commented on several drafts. I.O. recommended on the integration of human needs and bioeconomy. M.B., A.N., I.O. and S.S. contributed to the development of the BIO-SES framework, edited and commented on the article.

Funding: This research was funded by the Jubiläumsfonds of the Austrian National Bank (ÖNB) and is an outcome of the project 'Pathways towards a prosperous and just EU Bioeconomy' (Project nr. 17071).

Acknowledgments: We thank Pablo Piñero, Eveline van Leeuwen and three anonymous peer reviewers for their constructive feedback on earlier versions of the manuscript.

Conflicts of Interest: The authors declare no conflict of interest.

\section{References}

1. Heimann, T. Bioeconomy and Sustainable Development Goals (SDGs): Does the bioeconomy support the achievement of the SDGs? Earth's Future 2018, 7, 43-57. [CrossRef] 
2. Biobased Industries Consortium (Ed.) Bioeconomy and the UN Sustainable Development Goals; Biobased Industries Consortium: Brussels, Belgium, 2018.

3. Zeug, W.; Bezama, A.; Moesenfechtel, U.; Jähkel, A.; Thrän, D. Stakeholders' interests and perceptions of bioeconomy monitoring using a sustainable development goal framework. Sustainability 2019, 11, 1511. [CrossRef]

4. Pfau, S.; Hagens, J.; Dankbaar, B.; Smits, A. Visions of sustainability in bioeconomy research. Sustainability 2014, 6, 1222-1249. [CrossRef]

5. Aguilar, A.; Magnien, E.; Thomas, D. Thirty years of European biotechnology programmes: From biomolecular engineering to the bioeconomy. New Biotechnol. 2013, 30, 410-425. [CrossRef] [PubMed]

6. Lokko, Y.; Heijde, M.; Schebesta, K.; Scholtès, P.; Van Montagu, M.; Giacca, M. Biotechnology and the bioeconomy-Towards inclusive and sustainable industrial development. New Biotechnol. 2017, 40, 5-10. [CrossRef] [PubMed]

7. Parajuli, R.; Dalgaard, T.; Jørgensen, U.; Adamsen, A.P.S.; Knudsen, M.T.; Birkved, M.; Gylling, M.; Schjørring, J.K. Biorefining in the prevailing energy and materials crisis: A review of sustainable pathways for biorefinery value chains and sustainability assessment methodologies. Renew. Sustain. Energy Rev. 2015, 43, 244-263. [CrossRef]

8. Mohan, S.V.; Nikhil, G.; Chiranjeevi, P.; Reddy, C.N.; Rohit, M.; Kumar, A.N.; Sarkar, O. Waste biorefinery models towards sustainable circular bioeconomy: Critical review and future perspectives. Bioresour. Technol. 2016, 215, 2-12. [CrossRef]

9. German Bioeconomy Council. Bioeconomy Policy (Part III): Update Report of National Strategies Around the World; Office of the Bioeconomy Council: Berlin, Germany, 2018.

10. Dubois, O.; Gomez San Juan, M. How Sustainability is Addressed in Official Bioeconomy Strategies at International, National and Regional Levels: An Overview; Environment and Natural Resources Management. Working Paper no. 63; FAO: Rome, Italy, 2016.

11. Haarich, S.; Kirchmayr-Novak, S.; Fontenl, A.; Toptsidou, M.; Hans, S. Bioeconomy Development in EU Regions. Mapping of EU Member States' Regions' Research and Innovation Plans E Strategies for Smart Specialisation (RIS3) on Bioeconomy for 2014-2020; Study commissioned by DG Research \& Innovation; European Commission: Brussels, Belgium, 2017.

12. Lowe, P.; Marsden, T.; Whatmore, S. Regulating Agriculture; David Fulton Publishers: London, UK, 1994; p. 190.

13. WIFO. Über das BIP hinaus - Österreich auf dem Prüfstand erweiterter Wohlfahrtsmaße; Wirtschaftsforschungsinstitut: Wien, Austria, 2011.

14. DeFries, R.S.; Foley, J.A.; Asner, G.P. Land-use choices: Balancing human needs and ecosystem function. Front. Ecol. Environ. 2004, 2, 249-257. [CrossRef]

15. Geist, H.J.; Lambin, E.F. Proximate Causes and Underlying Driving Forces of Tropical Deforestation. BioScience 2002, 52, 143-150. [CrossRef]

16. Moran, D.; Kanemoto, K. Identifying species threat hotspots from global supply chains. Nat. Ecol. Evol. 2017, 1, 0023. [CrossRef]

17. IPCC. Summary for policymakers. In Global Warming of $1.5^{\circ} \mathrm{C}$ : An IPCC Special Report on the Impacts of Global Warming of $1.5^{\circ} \mathrm{C}$ Above pre-Industrial Levels and Related Global Greenhouse Gas Emission Pathways, in the Context of Strengthening the Global Response to the Threat of Climate Change, Sustainable Development, and Efforts to Eradicate Poverty; Masson-Delmotte, V., Zhai, P., Pörtner, H.O., Roberts, D., Skea, J., Shukla, P.R., Pirani, A., Moufouma-Okia, W., Péan, C., Pidcock, R., et al., Eds.; World Meteorological Organization: Geneva, Switzerland, 2018; p. 32.

18. Steffen, W.; Richardson, K.; Rockström, J.; Cornell, S.E.; Fetzer, I.; Bennett, E.M.; Biggs, R.; Carpenter, S.R.; de Vries, W.; de Wit, C.A. Planetary boundaries: Guiding human development on a changing planet. Science 2015, 1259855. [CrossRef] [PubMed]

19. Vermeulen, S.J.; Campbell, B.M.; Ingram, J.S. Climate change and food systems. Annu. Rev. Environ. Resour. 2012, 37, 195-222. [CrossRef]

20. Willett, W.; Rockström, J.; Loken, B.; Springmann, M.; Lang, T.; Vermeulen, S.; Garnett, T.; Tilman, D.; DeClerck, F.; Wood, A.; et al. Food in the Anthropocene: The EAT-Lancet Commission on healthy diets from sustainable food systems. Lancet 2019. [CrossRef] 
21. Schanes, K.; Dobernig, K.; Gözet, B. Food waste matters-A systematic review of household food waste practices and their policy implications. J. Clean. Prod. 2018, 182, 978-991. [CrossRef]

22. EC. The Impact of EU Consumption on Deforestation: Comprehensive Analysis of the Impact of EU Consumption on Deforestation; DG ENV Technical Report 2013-063; European Commission: Brussels, Belgium, 2013.

23. Bruckner, M.; Häyhä, T.; Giljum, S.; Maus, V.W.; Fischer, G.; Tramberend, S.; Boerner, J. Quantifying the global cropland footprint of the European Union's non-food bioeconomy. Environ. Res. Lett. 2019, 14, 1-12. [CrossRef]

24. Giljum, S.; Bruckner, M.; Gözet, B.; de Schutter, L. Land Under Pressure. Global Impacts of the EU Bioeconomy; Friends of the Earth Europe: Brussels, Belgium, 2016.

25. O'Brien, M.; Wechsler, D.; Bringezu, S.; Schaldach, R. Toward a systemic monitoring of the European bioeconomy: Gaps, needs and the integration of sustainability indicators and targets for global land use. Land Use Policy 2017, 66, 162-171. [CrossRef]

26. Giddings, B.; Hopwood, B.; O'brien, G. Environment, economy and society: Fitting them together into sustainable development. Sustain. Dev. 2002, 10, 187-196. [CrossRef]

27. Lewandowski, I. Bioeconomy: Shaping the Transition to a Sustainable, Biobased Economy; Springer: Berlin, Germany, 2017.

28. Camia, A.; Robert, N.; Jonsson, R.; Pilli, R.; García-Condado, S.; López-Lozano, R.; van der Velde, M.; Ronzon, T.; Gurría, P.; M’Barek, R.; et al. Biomass Production, Supply, Uses and Flows in the European Union. First Results from an Integrated Assessment; Publications Office of the European Union: Luxemburg, Luxembourg, 2018.

29. Purvis, B.; Mao, Y.; Robinson, D. Three pillars of sustainability: In search of conceptual origins. Sustain. Sci. 2018, 14, 681-695. [CrossRef]

30. Holling, C.S.; Berkes, F.; Folke, C. Science, sustainability and resource management. Link. Soc. Ecol. Syst. Manag. Pract. Soc. Mech. Build. Resil. 1998, 342, 350-352.

31. Berkes, F.; Folke, C.; Colding, J. Linking Social and Ecological Systems: Management Practices and Social Mechanisms for Building Resilience; Cambridge University Press: Cambridge, UK; New York, NY, USA, 1998; pp. xvi, 459.

32. MEA. Millennium Ecosystem Assessment: Ecosystems and Human Well-Being; Island Press: Washington, DC, USA, 2005.

33. Folke, C. Resilience: The emergence of a perspective for social-ecological systems analyses. Glob. Environ. Chang. 2006, 16, 253-267. [CrossRef]

34. Ostrom, E. A general framework for analyzing sustainability of social-ecological systems. Science 2009, 325, 419-422. [CrossRef] [PubMed]

35. Anderies, J.; Janssen, M.; Ostrom, E. A framework to analyze the robustness of social-ecological systems from an institutional perspective. Ecol. Soc. 2004, 9, art. 18. [CrossRef]

36. Liu, J.G.; Dietz, T.; Carpenter, S.R.; Alberti, M.; Folke, C.; Moran, E.; Pell, A.N.; Deadman, P.; Kratz, T.; Lubchenco, J.; et al. Complexity of coupled human and natural systems. Science 2007, 317, 1513-1516. [CrossRef] [PubMed]

37. Liu, J.; Hull, V.; Batistella, M.; DeFries, R.; Dietz, T.; Fu, F.; Hertel, T.W.; Izaurralde, R.C.; Lambin, E.F.; Li, S.; et al. Framing Sustainability in a Telecoupled World. Ecol. Soc. 2013, 18, 26. [CrossRef]

38. Bell, J.; Paula, L.; Dodd, T.; Nemeth, S.; Nanou, C.; Mega, V.; Campos, P. EU ambition to build the world's leading bioeconomy-Uncertain times demand innovative and sustainable solutions. New Biotechnol. 2018, 40, 25-30. [CrossRef] [PubMed]

39. OECD. The Bioeconomy to 2030: Designing a Policy Agenda; OECD: Paris, France, 2009.

40. European Commission. Innovating for Sustainable Growth: A Bioeconomy for Europe; DG Research and Innovation: Brussels, Belgium, 2012.

41. White House. National Bioeconomy Blueprint; White House: Washington, DC, USA, 2012.

42. Schütte, G. What kind of innovation policy does the bioeconomy need? New Biotechnol. 2018, 40, 82-86. [CrossRef]

43. EC. A Sustainable Bioeconomy for Europe: Strengthening the Connection between Economy, Society and the Environment-Updated Bioeconomy Strategy; Directorate-General for Research and Innovation, Ed.; European Commission: Brussels, Belgium, 2018; p. 103. [CrossRef]

44. Bugge, M.M.; Hansen, T.; Klitkou, A. What is the bioeconomy? A review of the literature. Sustainability 2016, 8, 691. [CrossRef] 
45. Ramcilovic-Suominen, S.; Pülzl, H. Sustainable development-A 'selling point'of the emerging EU bioeconomy policy framework? J. Clean. Prod. 2016, 172, 4170-4180. [CrossRef]

46. Gerber, J.-F.; Scheidel, A. In search of substantive economics: Comparing today's two major socio-metabolic approaches to the economy-MEFA and MuSIASEM. Ecol. Econ. 2018, 144, 186-194. [CrossRef]

47. Folke, C.; Biggs, R.; Norström, A.V.; Reyers, B.; Rockström, J. Social-ecological resilience and biosphere-based sustainability science. Ecol. Soc. 2016, 21, art. 41. [CrossRef]

48. Bruckmeier, K. Social-Ecological Transformation; Springer: Berlin, Germany, 2016.

49. Egenolf, V.; Bringezu, S. Conceptualization of an Indicator System for Assessing the Sustainability of the Bioeconomy. Sustainability 2019, 11, 443. [CrossRef]

50. Müller, A.; Sukhdev, P. Measuring What Matters in Agriculture and Food Systems. A Synthesis of the Results and Recommendations of Teeb for Agriculture and Food's Scientific and Economic Foundations Report; UN Environment: Geneva, Switzerland, 2018.

51. Scordato, L.; Bugge, M.M.; Fevolden, A.M. Directionality across diversity: Governing contending policy rationales in the transition towards the bioeconomy. Sustainability 2017, 9, 206. [CrossRef]

52. Hausknost, D.; Schriefl, E.; Lauk, C.; Kalt, G. A Transition to Which Bioeconomy? An Exploration of Diverging Techno-Political Choices. Sustainability 2017, 9, 669. [CrossRef]

53. Schmidt, O.; Padel, S.; Levidow, L. The bio-economy concept and knowledge base in a public goods and farmer perspective. Bio-Based Appl. Econ. 2012, 1, 47-63.

54. Marsden, T.; Farioli, F. Natural powers: From the bio-economy to the eco-economy and sustainable place-making. Sustain. Sci. 2015, 10, 331-344. [CrossRef]

55. Rockström, J.; Steffen, W.; Noone, K.; Persson, Å.; Chapin, F.S., I; Lambin, E.; Lenton, T.M.; Scheffer, M.; Folke, C.; Schellnhuber, H.; et al. Planetary Boundaries: Exploring the Safe Operating Space for Humanity. Ecol. Soc. 2009, 14, art. 32.

56. Springmann, M.; Clark, M.; Mason-D'Croz, D.; Wiebe, K.; Bodirsky, B.L.; Lassaletta, L.; de Vries, W.; Vermeulen, S.J.; Herrero, M.; Carlson, K.M. Options for keeping the food system within environmental limits. Nature 2018, 562, 519. [CrossRef]

57. Conijn, J.; Bindraban, P.; Schröder, J.; Jongschaap, R. Can our global food system meet food demand within planetary boundaries? Agric. Ecosyst. Environ. 2018, 251, 244-256. [CrossRef]

58. Raworth, K. A safe and just space for humanity: Can we live within the doughnut. Oxfam Policy Pract. Clim. Chang. Resil. 2012, 8, 1-26.

59. Raworth, K. Perspectives and Pathways Ahead. In Proceedings of the Growth in Transition Conference, Vienna, Austria, 14-15 November 2018; Available online: https://vimeo.com/300946012,34\$'\$ (accessed on 15 January 2019).

60. Holden, E.; Linnerud, K.; Banister, D. The imperatives of sustainable development. Sustain. Dev. 2017, 25, 213-226. [CrossRef]

61. Costanza, R.; Fisher, B.; Ali, S.; Beer, C.; Bond, L.; Boumans, R.; Danigelis, N.L.; Dickinson, J.; Elliott, C.; Farley, J. Quality of life: An approach integrating opportunities, human needs, and subjective well-being. Ecol. Econ. 2007, 61, 267-276. [CrossRef]

62. Rauschmayer, F.; Omann, I.; Frühmann, J. Needs, capabilities and quality of life: Refocusing sustainable development. In Sustainable Development; Rauschmayer, F., Omann, I., Frühmann, J., Eds.; Routledge Studies in Ecological Economics: New York, NY, USA, 2012; pp. 1-24.

63. Koch, M.; Buch-Hansen, H.; Fritz, M. Shifting priorities in degrowth research: An argument for the centrality of human needs. Ecol. Econ. 2017, 138, 74-81. [CrossRef]

64. Gabriel, C.-A.; Bond, C. Need, Entitlement and Desert: A Distributive Justice Framework for Consumption Degrowth. Ecol. Econ. 2019, 156, 327-336. [CrossRef]

65. Brand-Correa, L.I.; Steinberger, J.K. A Framework for Decoupling Human Need Satisfaction From Energy Use. Ecol. Econ. 2017, 141, 43-52. [CrossRef]

66. Vita, G.; Hertwich, E.; Stadler, K.; Wood, R. Connecting global emissions to fundamental human needs and their satisfaction. Environ. Res. Lett. 2018, 14, 1-16. [CrossRef]

67. Steinberger, J.K.; Roberts, J.T. From constraint to sufficiency The decoupling of energy and carbon from human needs, 1975-2005. Ecol. Econ. 2010, 70, 425-433. [CrossRef] 
68. Max-Neef, M.A. Development and human needs. In Real-Life Economics: Understanding Wealth Creation; Ekins, P., Max-Neef, M.A., Eds.; Routledge: London, UK; New York, NY, USA, 1992.

69. Doyal, L.; Gough, I. A Theory of Human Need; Guilford Press: New York, NY, USA, 1991; p. xvi, 365.

70. Schmidt-Traub, G. On Metrics and Financing for the Sustainable Development Goals. Ph.D. Thesis, Wageningen University, Wageningen, The Netherlands, 2018.

71. Waage, J.; Yap, C.; Bell, S.; Levy, C.; Mace, G.; Pegram, T.; Unterhalter, E.; Dasandi, N.; Hudson, D.; Kock, R. Governing the UN Sustainable Development Goals: Interactions, infrastructures, and institutions. Lancet Glob. Health 2015, 3, e251-e252. [CrossRef]

72. Schoon, M.; Van der Leeuw, S. The shift toward social-ecological systems perspectives: Insights into the human-nature relationship. Nat. Sci. Sociétés 2015, 23, 166-174. [CrossRef]

73. Daly, H.E. Economics for a Full World. Great Transition Initiative. Tellus Institute: Cambridge, MA, USA. Available online: https://greattransition.org/publication/economics-for-a-full-world (accessed on 1 March 2019).

74. Daly, H.E.; Farley, J. Ecological Economics: Principles and Applications; Island Press: Washington, DC, USA, 2011.

75. Venkatesan, M. Fostering sustainable bioeconomies: The role of conscious consumption. In Towards a Sustainable. Bioeconomy: Principles, Challenges and Perspectives; Leal Filho, W., Mihaela Pociovălișteanu, D., Borges de Brito, P.R., Borges de Lima, I.E., Eds.; Springer: Berlin, Germany, 2018.

76. Spash, C.L. Social Ecological Economics. In Routledge Handbook of Ecological Economics; Spash, C.L., Ed.; Routledge: New York, NY, USA, 2017; pp. 3-16.

77. Cato, M.S. The bioregional economy celebrating the local in production and consumption. In Routledge Handbook of Ecological Economics; Spash, C.L., Ed.; Routledge: New York, NY, USA, 2017; pp. 487-496.

78. Haberl, H.; Fischer-Kowalski, M.; Krausmann, F.; Weisz, H.; Winiwarter, V. Progress towards sustainability? What the conceptual framework of material and energy flow accounting (MEFA) can offer. Land Use Policy 2004, 21, 199-213. [CrossRef]

79. Fischer-Kowalski, M.; Haberl, H. Metabolism and Colonization. Modes of Production and the Physical Exchange between Societies and Nature. Innov. Soc. Res. 1993, 6, 415-442. [CrossRef]

80. Rauschmayer, F.; Omann, I. Needs as a central element of sustainable development. In Routledge Handbook of Ecological Economics; Spash, C.L., Ed.; Routledge: New York, NY, USA, 2017; pp. 246-255.

81. Folke, C.; Hahn, T.; Olsson, P.; Norberg, J. Adaptive governance of social-ecological systems. Annu. Rev. Environ. Resour. 2005, 30, 441-473. [CrossRef]

82. Max-Neef, M. Human-Scale Development-Conception, Application and Further Reflection; Apex Press: London, UK, 1991.

83. Monforti-Ferrario, F.; Pascua, I.P. Energy Use in the EU Food Sector: State of Play and Opportunities for Improvement; Publications Office of the European Union: Luxembourg, Luxembourg, 2015.

84. Holling, C.S. Resilience and stability of ecological systems. Annu. Rev. Ecol. Syst. 1973, 4, 1-23. [CrossRef]

85. Ostrom, E. Governing the Commons: The Evolution of Institutions for Collective Action; Cambridge University Press: Cambridge, NY, USA, 1990; pp. xviii, 280.

86. Odum, E.P.; Odum, H. Fundamentals of Ecology; W.B. Saunders Co.: Philadelphia, PA, USA, 1953; p. 387.

87. Tilly, L.J. The structure and dynamics of Cone Spring. Ecol. Monogr. 1968, 38, 169-197. [CrossRef]

88. Vernadsky, V.I. The Biosphere; Springer Science \& Business Media: New York, NY, USA, 2012.

89. Walker, B.; Salt, D. Resilience Thinking: Sustaining Ecosystems and People in a Changing World; Island Press: Washington DC, USA, 2012.

90. Martínez-Fernández, J.; Esteve, M. A critical view of the desertification debate in southeastern Spain. Land Degrad. Dev. 2005, 16, 529-539. [CrossRef]

91. Bonhommeau, S.; Dubroca, L.; Le Pape, O.; Barde, J.; Kaplan, D.M.; Chassot, E.; Nieblas, A.-E. Eating up the world's food web and the human trophic level. Proc. Natl. Acad. Sci. USA 2013, 110, 20617-20620. [CrossRef]

92. Roopnarine, P.D. Humans are apex predators. Proc. Natl. Acad. Sci. USA 2014, 111, E796. [CrossRef]

93. Goulson, D. An overview of the environmental risks posed by neonicotinoid insecticides. J. Appl. Ecol. 2013, 50, 977-987. [CrossRef]

94. Foster, G.; Dobernig, K.; Gruszka, K.; Schanes, K.; de Schutter, L. Sustainable Consumption and Production (Chapter 5). In Towards a Socio-Ecological Transformation of the Economy; Institute for Ecological Economics, Vienna University of Economics and Business: Vienna, Austria, 2019; pp. 60-73. 
95. Ceaușu, S.; Hofmann, M.; Navarro, L.M.; Carver, S.; Verburg, P.H.; Pereira, H.M. Mapping opportunities and challenges for rewilding in Europe. Conserv. Biol. 2015, 29, 1017-1027. [CrossRef]

96. Hardin, G. The Tragedy of the Commons. Science 1968, 162, 1243-1248.

97. Mol, A.P.; Buttel, F.H. The environmental state under pressure: An introduction. In The Environmental State Under Pressure; Emerald Group Publishing Limited: Bingley, UK, 2002; p. 33.

98. Amblard, L. The potential of collective action for the control of nonpoint source pollution in European rural areas. In Proceedings of the Design and Dynamics of Institutions for Collective Action Conference, Utrecht, The Netherlands, 29 November-1 December 2012.

99. Poteete, A.R.; Janssen, M.A.; Ostrom, E. Working Together: Collective Action, the Commons, and Multiple Methods in Practice; Princeton University Press: Princeton, NJ, USA, 2010.

100. Lara, A. Rationality and complexity in the work of Elinor Ostrom. Int. J. Commons 2015, 9, 573-594. [CrossRef]

101. Van Vliet, J.; de Groot, H.L.; Rietveld, P.; Verburg, P.H. Manifestations and underlying drivers of agricultural land use change in Europe. Landsc. Urban Plan. 2015, 133, 24-36. [CrossRef]

102. Martín-López, B.; Palomo, I.; García-Llorente, M.; Iniesta-Arandia, I.; Castro, A.J.; Del Amo, D.G.; Gómez-Baggethun, E.; Montes, C. Delineating boundaries of social-ecological systems for landscape planning: A comprehensive spatial approach. Land Use Policy 2017, 66, 90-104. [CrossRef]

103. Fournier, V. Commoning: On the social organisation of the commons. M@ N@ Gement 2013, 16, 433-453. [CrossRef]

104. Kircher, M. The Emerging Bioeconomy: Industrial Drivers, Global Impact, and International Strategies. Ind. Biotechnol. 2014, 10, 11-18. [CrossRef]

105. Kircher, M. The transition to a bio-economy: National perspectives. Biofuelsbioprod. Biorefin. 2012, 6, $240-245$. [CrossRef]

106. Wallerstein, I. World-Systems Analysis; Duke University Press: Durham, NC, USA, 2004; p. 109.

107. Hornborg, A. Uneven development as a result of the unequal exchange of time and space: Some conceptual issues. J. Fur. Entwickl. 2010, 26, 36-56. [CrossRef]

108. Liu, J.; Mooney, H.; Hull, V.; Davis, S.J.; Gaskell, J.; Hertel, T.; Lubchenco, J.; Seto, K.C.; Gleick, P.; Kremen, C. Systems integration for global sustainability. Science 2015, 347, 1258832. [CrossRef] [PubMed]

109. Eakin, H.; Rueda, X.; Mahanti, A. Transforming governance in telecoupled food systems. Ecol. Soc. 2017, 22, art. 32. [CrossRef]

110. Silva, R.; Batistella, M.; Dou, Y.; Moran, E.; Torres, S.; Liu, J. The Sino-Brazilian telecoupled soybean system and cascading effects for the exporting country. Land 2017, 6, 53. [CrossRef]

111. Friis, C.; Nielsen, J.Ø. On the system. Boundary choices, implications, and solutions in telecoupling land use change research. Sustainability 2017, 9, 974. [CrossRef]

112. Coe, N.M.; Kelly, P.F.; Yeung, H.W.-C. Economic Geography: A Contemporary Introduction; Blackwell Oxford: Oxford, UK, 2007; p. 6.

113. Binder, C.R.; Hinkel, J.; Bots, P.W.; Pahl-Wostl, C. Comparison of frameworks for analyzing social-ecological systems. Ecol. Soc. 2013, 18, 26. [CrossRef]

114. Ostrom, E. A diagnostic approach for going beyond panaceas. Proc. Natl. Acad. Sci. USA 2007, 104, 15181-15187. [CrossRef] [PubMed]

115. Epstein, G.; Vogt, J.M.; Mincey, S.K.; Cox, M.; Fischer, B. Missing ecology: Integrating ecological perspectives with the social-ecological system framework. Int. J. Commons 2013, 7, 432-453. [CrossRef]

116. Vogt, J.M.; Epstein, G.B.; Mincey, S.K.; Fischer, B.C.; McCord, P. Putting the "E" in SES: Unpacking the ecology in the Ostrom sociale-cological system framework. Ecol. Soc. 2015, 20, 55. [CrossRef]

117. Godar, J.; Gardner, T. Trade and Land-Use Telecouplings. In Telecoupling; Springer: Berlin, Germany, 2019; pp. 149-175.

118. Duchin, F. Resources for sustainable economic development: A framework for evaluating infrastructure system alternatives. Sustainability 2017, 9, 2105. [CrossRef]

119. Courtonne, J.-Y.; Alapetite, J.; Longaretti, P.-Y.; Dupré, D.; Prados, E. Downscaling material flow analysis: The case of the cereal supply chain in France. Ecol. Econ. 2015, 118, 67-80. [CrossRef]

120. Sun, Z.; Tukker, A.; Behrens, P. Going Global to Local: Connecting Top-Down Accounting and Local Impacts, A Methodological Review of Spatially Explicit Input-Output Approaches. Environ. Sci. Technol. 2018, 53, 1048-1062. [CrossRef] 
121. Chen, G.; Hadjikakou, M.; Wiedmann, T. Urban carbon transformations: Unravelling spatial and inter-sectoral linkages for key city industries based on multi-region input-output analysis. J. Clean. Prod. 2017, 163, 224-240. [CrossRef]

122. Mustalahti, I. The responsive bioeconomy: The need for inclusion of citizens and environmental capability in the forest based bioeconomy. J. Clean. Prod. 2017, 30, 1e10. [CrossRef]

123. Kammerlander, M.; de Schutter, L.; Omann, I. The Bioeconomy we need (Manuscript in preparation).

124. Chater, N.; Loewenstein, G. The under-appreciated drive for sense-making. J. Econ. Behav. Organ. 2016, 126, 137-154. [CrossRef]

125. Smith, C.; Rassia, S.; Delioglanis, I. Region-Specific Social Innovation and Community Energy Approaches with an Application Potential in Biogas. In Triggering Sustainable Biogas Energy Communities Through Social Innovation; ISABEL Consortium, 2016.

126. Harris, P.G. Common but differentiated responsibility: The kyoto protocol and United States policy. N.Y.U Environ. Law J. 1999, 7, 27.

127. Global Commons Institute. Contraction and Convergence (in the context of climate policy). 1989. Available online: http://www.gci.org.uk/links.html (accessed on 15 September 2019).

128. Kitzes, J.; Wackernagel, M.; Loh, J.; Peller, A.; Goldfinger, S.; Cheng, D.; Tea, K. Shrink and share: Humanity's present and future Ecological Footprint. Philos. Trans. R. Soc. B Biol. Sci. 2007, 363, 467-475. [CrossRef] [PubMed]

129. Meuleman, L.; Niestroy, I. Common but differentiated governance: A metagovernance approach to make the SDGs work. Sustainability 2015, 7, 12295-12321. [CrossRef]

130. Steurer, R. Disentangling governance: A synoptic view of regulation by government, business and civil society. Policy Sci. 2013, 46, 387-410. [CrossRef]

131. Dietz, T.; Börner, J.; Förster, J.; von Braun, J. Governance of the bioeconomy: A global comparative study of national bioeconomy strategies. Sustainability 2018, 10, 3190. [CrossRef]

132. Marsden, T. Exploring the rural eco-economy: Beyond neoliberalism. Sociol. Rural. 2016, 56, 597-615. [CrossRef]

133. Alessandrini, M.; Celotti, P.; Dallhammer, E.; Gorny, H.; Gramillano, A.; Schuh, B.; Zingaretti, C. Implementing a Place-Based Approach to EU Industrial Policy Strategy; Commission for Economic Policy, Ed.; European Committee of the Regions, European Union: Brussels, Belgium, 2019.

134. Queensland Government. Framework for Place-Based Approaches. Supporting our Future State: Advancing Queensland's Priorities. Available online: https://www.communities.qld.gov.au/community/ place-based-approaches/overview (accessed on 15 September 2019).

135. Niestroy, I. Sustainable Development Goals at the Subnational Level: Roles and Good Practices for Subnational Governments; The 2014 Regional Sustainable Development Transition Series. SDplanNet Briefing Note; IISD: Winnipeg, Canada, 2014; p. 9.

136. UN High Level Political Forum. 2017 HLPF Thematic Review of SDG 2: End hunger, achieve food security and improved nutrition, and promote sustainable agriculture. 2017. Available online: https://sustainabledevelopment.un.org/content/documents/14371SDG2_format.revised_FINAL_28_ 04.pdf (accessed on 17 September 2019).

137. UN High Level Political Forum. 2017 HLPF Thematic Review of SDG 1: End Poverty in All its Forms Everywhere. 2017. Available online: https://sustainabledevelopment.un.org/content/documents/ 14379SDG1format-final_OD.pdf (accessed on 17 September 2019).

138. Verones, F.; Moran, D.; Stadler, K.; Kanemoto, K.; Wood, R. Resource footprints and their ecosystem consequences. Sci. Rep. 2017, 7, 40743. [CrossRef]

139. Kuhmonen, T.; Kuhmonen, I. Rural futures in developed economies: The case of Finland. Technol. Forecast. Soc. Chang. 2015, 101, 366-374. [CrossRef]

140. Conallin, J.C.; Dickens, C.; Hearne, D.; Allan, C. Stakeholder engagement in environmental water management. In Water for the Environment; Elsevier: Amsterdam, The Netherlands, 2017; pp. 129-150.

(C) 2019 by the authors. Licensee MDPI, Basel, Switzerland. This article is an open access article distributed under the terms and conditions of the Creative Commons Attribution (CC BY) license (http://creativecommons.org/licenses/by/4.0/). 